Journal of

Dentistry and Oral Health

\title{
Solitary Intraosseous Mandibular Neurofibroma: Clinical Case Study
}

\author{
Kevin Fortier ${ }^{1, *}$, Shamit Prabhu ${ }^{2}$, Linda G. Levin ${ }^{3}$, Tiffany Peters ${ }^{4}$, Uday N. Reebye ${ }^{5}$ \\ ${ }^{1}$ DMD Candidate, Boston University Henry M. Goldman School of Dental Medicine \\ ${ }^{2}$ Masters of Physiology Candidate, North Carolina State University \\ ${ }^{3}$ Endodontist, Levin Endodontics \\ ${ }^{4}$ Oral and Maxillofacial Pathologist, Triangle Implant Center \\ ${ }^{5}$ Oral and Maxillofacial Surgeon, Triangle Implant Center
}

${ }^{\star}$ Corresponding author: Kevin Fortier, DMD Candidate, 50 Malden Street, Apartment \#219, Boston, MA 02118, Tel: (919) 744-9325; E-mail: kevinfortier93@gmail.com

Received Date: December 13, 2017; Accepted Date: January 17, 2018; Published Date: January 19, 2018

Citation: Kevin Fortier, et al. (2018) Solitary Intraosseous Mandibular Neurofibroma: Clinical Case Study. J Dent Oral Health 5: $1-7$.

\begin{abstract}
\section{Introduction}

A neurofibroma, according to the World Health Organization, is "a benign tumor of the peripheral nerve sheath phenotype with mixed cellular componentswhich includes Schwann cells, perineural hybrid cells, and intraneural fibroblasts."

Neurofibromas can be caused due to the inactivation/ mutation of NF1 gene which encodes for the protein, neurofibromin, known to play a role in cell signaling [1]. The presence of neurofibromas can be multiple or solitary. Neurofibromas are most commonly found in the skin and its multiple appearances is highly associated with von Recklinghausen's disease and poliglandular syndrome MEN III [2]. A solitary neurofibroma is a single lesion that occurs in an individual who does not have hereditary neurofibromatosis. This condition may be difficult to identify at first because a single neurofibroma may be the first sign of neurofibromatosis [3].
\end{abstract}

A neurofibroma is a benign neurogenic tumor of the peripheral nerve sheath with variable cellular components. The treatment of this neurofibroma required surgical excision. The following report describes a case of a solitary intraosseous mandibular neurofibroma in a 70-year-old female located in the right posterior mandible. Clinical findings and radiographic evidence, along with histopathological evaluation and immunohistochemistry, confirmed the diagnosis of neurofibroma. Due to rare occurrence of neurofibromas presenting intraorally in the mandible, this case was deemed necessary for documentation. A literature review detailing prior cases of intraosseous neurofibromas is also presented in this report.

Keywords: Solitary neurofibroma; Benign tumor; Intraosseous; Nerve sheath; Mandible

(C)2018 The Authors. Published by the JScholar under the terms of the Creative Commons Attribution License http://creativecommons.org/licenses/by/3.0/, which permits unrestricted use, provided the original author and source are credited.
In 1954, Bruce gave the first description of solitary neurofibroma of the oral cavity. Since then, only a few cases have been documented in the literature. The various sites of occurrence intraorally in the soft tissue are the tongue, floor of mouth, buccal mucosa, edentulous alveolar ridge, gingiva and pharyngomaxillary spaces [4]. In this report, we discuss a case of a 70 -year-old female patient who presented with a solitary neurofibroma of the mandible along with review of the clinical and histological examination.

\section{Case Report}

\section{Evaluation}

A 70-year-old female was referred for evaluation of lytic lesion of the right posterior mandible. She had been seen by her dentist who had seen a large periapical lesion associated with tooth number 31 on a panoramic radiograph (Figure 1). She was referred for endodontic evaluation and treatment. Upon endodontic evaluation, the tooth was found to be vital, and her endodontist referred the patient for evaluation of lytic lesion and surgical treatment. A pre-operative cone bone CT was taken for enhanced visualization of the lesion (Figure 2). 


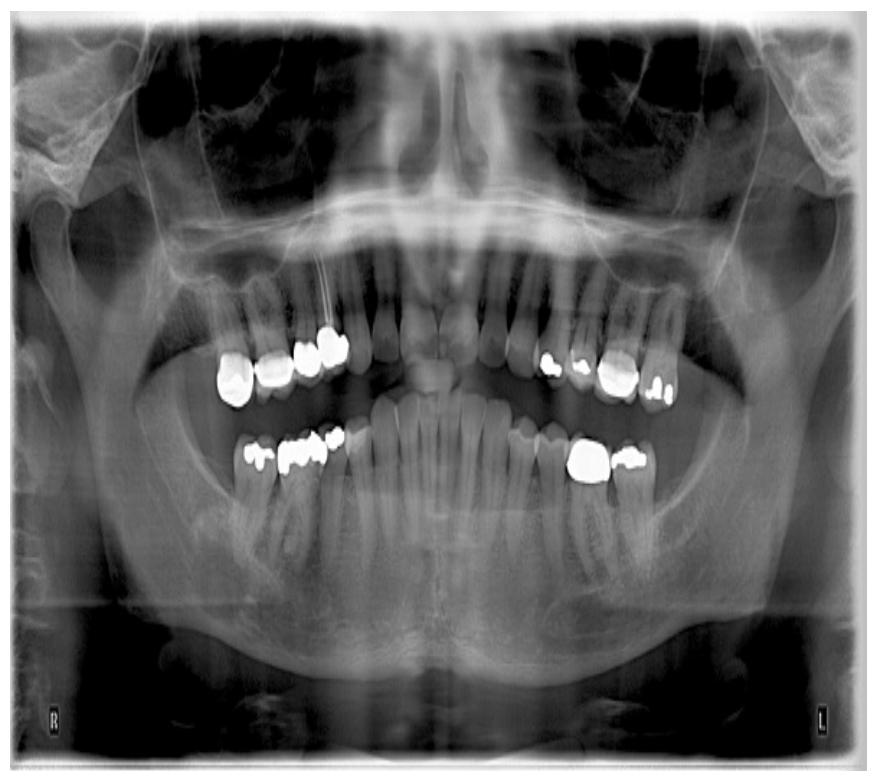

Figure 1. Pre-operative panoramic radiograph revealing periapical lesion associated with tooth \#31.

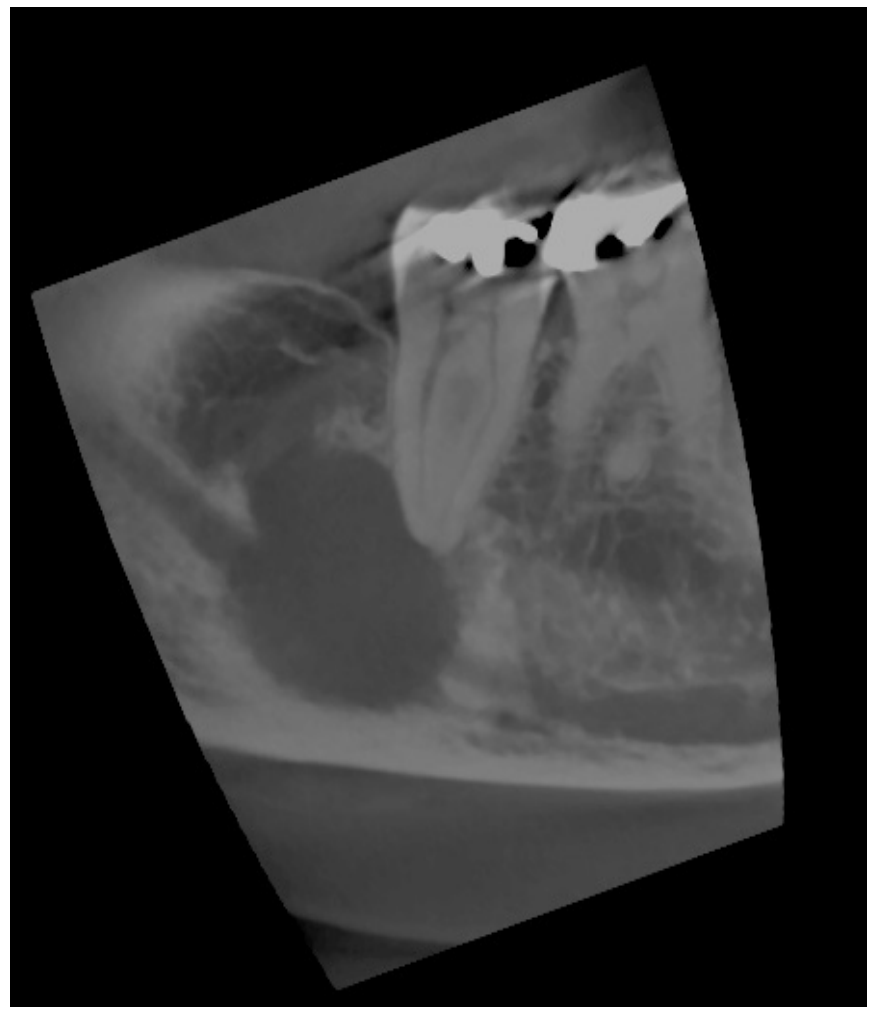

Figure 2. Pre-operative cone beam CT scan revealing enhanced visualization of the lesion in the longitudinal plane.

Evaluation of the patient demonstrated a healthy 70 -year-old female with no contributory medical issues. Clinically, there was no expansion of the lower right mandible either on the buccal or lingual aspects. The tooth was found to be vital. Surgical decision was made for a biopsy of the area.

\section{Surgical Technique}

The patient was anesthetized under general anesthesia. The vestibular incision was made on the lower right mandible with a distal vertical release. A full-thickness mucoperiosteal flap was elevated. A bony window was made. The lesion was identified immediately after removal of the window. The lesion was firmed and curettage able to enucleate vast majority of the lesion. There was adherence to inferior alveolar nerve. Both blunt and sharp dissections were completed to remove the lesion off the inferior alveolar nerve. The specimen was sent to pathology for histopathological evaluation. Surgical follow-up showed no postoperative complications.

\section{Post-Operative}

To address concerns surrounding post-operative healing of the patient, several follow-up appointments were scheduled with the patient with the longest duration follow-up at 1 year. A cone beam computed tomography (CBCT) scan was performed at the 1 year follow up (Figure 3). Not only does this scan show good bone fill in the region of the neurofibroma, but also vitality testing of the adjacent teeth performed by both the patient's oral surgeon and endodontist demonstrated that the teeth in question remained vital at 1 year postop. It should be noted that the patient demonstrated an initial patch of paresthesia on the lower right lip; however, this resolved over the course of six months. An extended follow-up period (past 1 year) for this particular patient was not carried out due to patient cooperativity.

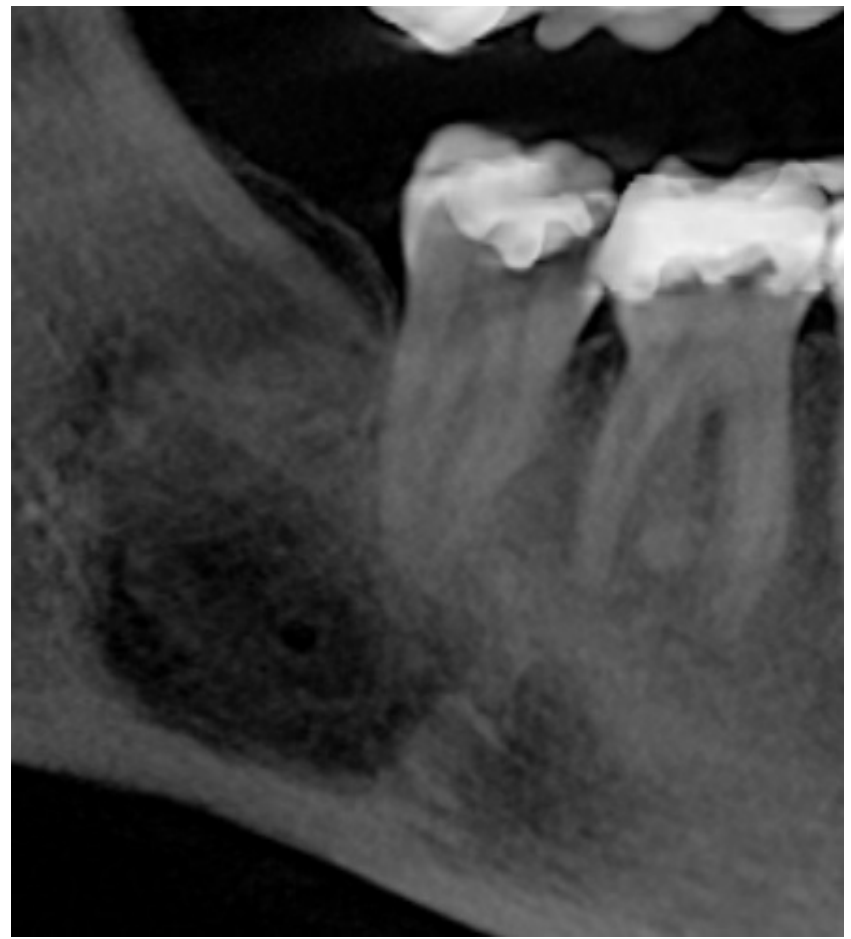

Figure 3. Post-operative cone beam CT scan after 1 year. 


\section{Histopathological Features}

The histopathological evaluation was conducted through the Department of Pathology at North Shore Long Island Jewish Medical Center. The specimen was preserved in formalin and consisted of two pieces of tan soft tissue. The appearance of the specimen measured $1.5 \times 0.7 \times 0.6 \mathrm{~cm}$. Histopathological evaluation indicated a benign neural neoplasm consistent with neurofibroma. Features included spindle shaped bundles of cells with wavy nuclei and admixture of predominantly inferior alveolar nerve fibers and fibrous tissue. Immunohistochemistry revealed positive staining for S100 protein. Figures 4 and 5 show histological staining of the sample at 20x and 60x magnification, respectively.

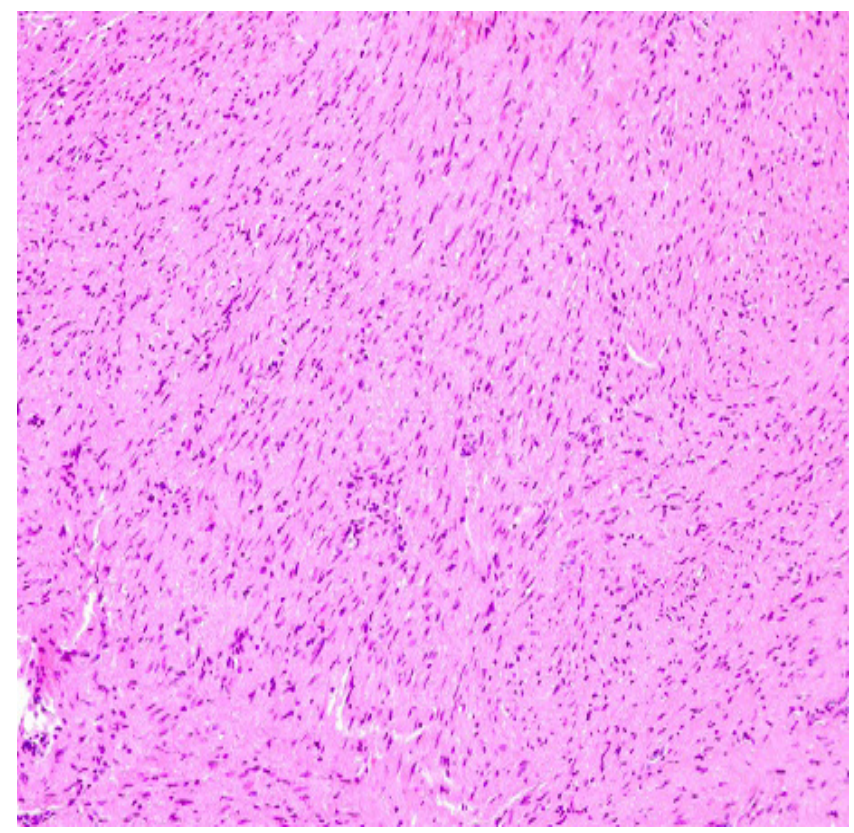

Figure 4 . Histological staining at 20x magnification.

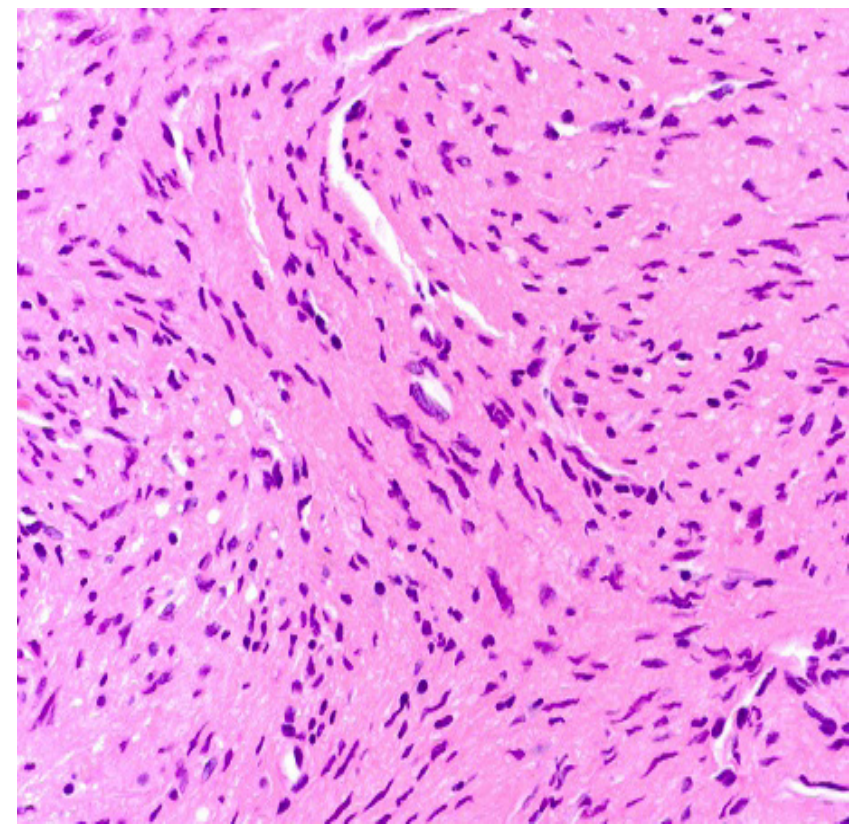

Figure 5. Histological staining at 60x magnification.

\section{Discussion}

Neurofibromas (NF) are neurogenic neoplasms that originate from the cells that constitute the nerve sheath. It is for this reason that solitary neurofibromas should be carefully evaluated to eliminate the possibility of Von Recklinghausens disease [7]. In the oral cavity, NFs often involve the trigeminal and upper cervical nerves. A literature review was performed using keywords "solitary neurofibroma of mandible" and the results have been summarized in Table I. When solitary neurofibroma occurred in the mandible, there was definite female predilection.

The head and neck are commonly involved because of rich innervations in this area. In terms of occurrence, roughly $25 \%$ of neurofibromas are observed in the head and neck region; only $5.6 \%$ of neurofibromas occur in the oral cavity [33]. Superficial involvement of soft tissue with NFs is more frequent than deeper locations. In the oral cavity, NF is reported to occur on the tongue, lip, palate, gingiva, major salivary glands, and the jaw bones $[3,5]$.

It has been discovered that NF is caused by a mutation in the NF1 gene located at 17q11.2 chromosome. This gene is tumor suppressing and encodes for the protein neurofibromin, which is involved in neural cell signaling [34].

Most intraosseous NFs present asymptomatic in the early stages, with possible pain and numbness on affected side presenting in the later stages [5]. Radiologically, the tumor appears as a nonspecific, unilocular or multilocular, poorly defined or well demarcated, radiolucency [10]. Histopathologically, NFs exhibit an irregular pattern with interlacing bundles of spindle shaped cells with round or fusiform nuclei, and eosinophilic cytoplasm within a loose myxomatous matrix of fine fibrillar collagen.

NFs are unencapsulated and composed of a mixture of Schwann, perineural-like and fibroblastic cells. Mast cells, lymphocytes, and small nerve fascicles can also be seen in the tumor $[5,12,15]$. NFs are immunopositive for S-100 protein, indicating its neural origin. Histopathological analysis supported by immunohistochemistry is essential for the correct diagnosis of these oral soft tissue growths [5].

It is important to differentiate NFs from other spindle cell lesions such as schwannomas. Although NFs and schwannomas are both benign tumors of the peripheral nerve sheath, the absence of verocay bodies and the presence of mast cells and fine fibrillary collagen matrix should distinguish NFs from schwannomas [35]. Furthermore, there are slight anatomical considerations associated with these tumors as well. Schwannomas will typically displace the root of the nerve they are associated with, while NFs will attempt to encase the nerve fiber. This anatomical difference was observed with this case report due to adherence to the inferior alveolar nerve. Due to this consideration, complete surgical removal of a solitary neurofibroma is difficult and may attribute to cases of recurrence. 
Table 1: Clinical, radiographic, histological and immunohistochemistry features of reported intraosseous neurofibroma of the mandible.

\begin{tabular}{|c|c|c|c|c|c|}
\hline References & $\begin{array}{l}\text { Age } \\
\text { (yrs) }\end{array}$ & Gender & Radiographic features & Histological features & $\begin{array}{l}\text { Immunohis to- } \\
\text { chemistry features }\end{array}$ \\
\hline Reebye 2017 & 70 & $\mathrm{~F}$ & $\begin{array}{l}\text { Well-defined radiolucent } \\
\text { region }\end{array}$ & $\begin{array}{l}\text { Spindle shaped bundles of cells with } \\
\text { wavy nuclei and admixture of predomi- } \\
\text { nantly inferior alveolar nerve fibers and } \\
\text { fibrous tissue }\end{array}$ & S-100 positive \\
\hline $\begin{array}{l}\text { Gujjar } \\
2015[5]\end{array}$ & 28 & $\mathrm{~F}$ & $\begin{array}{l}\text { Homogenous radioopac- } \\
\text { ity surrounded by a thin } \\
\text { uniform radiolucent } \\
\text { border }\end{array}$ & $\begin{array}{l}\text { spindle shaped cells with wavy nuclei } \\
\text { and collagen fibres within a myxoid } \\
\text { stroma }\end{array}$ & S-100 positive \\
\hline $\begin{array}{l}\text { Jagnam } \\
2014[6]\end{array}$ & 62 & $\mathrm{~F}$ & $\begin{array}{l}\text { Well-defined radiolu- } \\
\text { cency }\end{array}$ & $\begin{array}{l}\text { admixture of nerve fibers (mostly infe- } \\
\text { rior alveolar nerve) and fibrous tissue; } \\
\text { no malignancy }\end{array}$ & S-100 positive \\
\hline $\begin{array}{l}\text { Diechler } \\
2011[7]\end{array}$ & 14 & M & Unilateral radiolucency & $\begin{array}{l}\text { regular spindle cells with wavy, hyper- } \\
\text { chromatic nuclei and scanty cytoplasm, } \\
\text { in a richly vascularized myxoide stroma, } \\
\text { with presence of collagen fibers and } \\
\text { connective tissue cells }\end{array}$ & $\begin{array}{l}\text { Tumor cells: vi- } \\
\text { mentin positive, } \\
\text { neuroespecific eno- } \\
\text { lase (NSE) posi- } \\
\text { tive and anti S-100 } \\
\text { negative Residual } \\
\text { nerve fibers: S-100 } \\
\text { positive; NSE posi- } \\
\text { tive }\end{array}$ \\
\hline Tao 2010[8] & 16 & $\mathrm{~F}$ & $\begin{array}{l}\text { Multilocular and irregu- } \\
\text { lar edges }\end{array}$ & $\begin{array}{l}\text { spindle-shaped, aligned in a plexiform } \\
\text { manner }\end{array}$ & S-100 positive \\
\hline $\begin{array}{l}\text { Depprich } \\
2009[9]\end{array}$ & 64 & M & $\begin{array}{l}\text { Little to moderate inter- } \\
\text { dental loss of bone be- } \\
\text { tween teeth } 37 \text { and } 38\end{array}$ & $\begin{array}{l}\text { proliferative spindle cells with a stroma } \\
\text { composed of irregular collagen fibers }\end{array}$ & S-100 positive \\
\hline $\begin{array}{l}\text { Vivek } \\
2006[4]\end{array}$ & 39 & $\mathrm{~F}$ & $\begin{array}{l}\text { Well-circumscribed ra- } \\
\text { diolucency }\end{array}$ & $\begin{array}{l}\text { spindle shaped cells with wavy and ta- } \\
\text { pered nuclei }\end{array}$ & $\begin{array}{l}\text { Lack of encapsula- } \\
\text { tion; S-100 positive }\end{array}$ \\
\hline $\begin{array}{l}\text { Apostolidis } \\
2001[10]\end{array}$ & 67 & $\mathrm{~F}$ & $\begin{array}{l}\text { Well circumscribed and } \\
\text { elliptical radiolucency }\end{array}$ & $\begin{array}{l}\text { spindle shaped cells with wavy nuclei } \\
\text { and collagen fibres within a myxoid } \\
\text { matrix along with mast cells; No malig- } \\
\text { nancy }\end{array}$ & Not reported \\
\hline $\begin{array}{l}\text { Alatli } \\
1996[11]\end{array}$ & 37 & $\mathrm{~F}$ & No abnormality & $\begin{array}{l}\text { spindle cells arranged to form roundish } \\
\text { foci and wavy, thin bands within fibrous } \\
\text { connective tissue }\end{array}$ & Not reported \\
\hline $\begin{array}{l}\text { Ueda } \\
1993[12]\end{array}$ & 37 & M & Oval radiolucent area & $\begin{array}{l}\text { Spindle shaped cells intermingled with a } \\
\text { delicate fibrillar stroma along with nu- } \\
\text { merous mast cells }\end{array}$ & S 100 positive \\
\hline $\begin{array}{l}\text { Papageorge } \\
1992[13]\end{array}$ & 4.5 & M & $\begin{array}{l}\text { Unilocular, well-defined } \\
\text { radiolucency }\end{array}$ & $\begin{array}{l}\text { spindle cells with slight to moderate nu- } \\
\text { clear pleomorphism }\end{array}$ & $\begin{array}{l}\text { S-100 protein and } \\
\text { vimentin positive }\end{array}$ \\
\hline $\begin{array}{l}\text { Weaver } \\
1991[14]\end{array}$ & 22 & $\mathrm{~F}$ & $\begin{array}{l}\text { Radiolucent, well-cir- } \\
\text { cumscribed lesion }\end{array}$ & $\begin{array}{l}\text { Spindle shaped cells and flowing bun- } \\
\text { dles of cellular connective tissue }\end{array}$ & S-100 positive \\
\hline $\begin{array}{l}\text { Polak } \\
1989[15]\end{array}$ & 60 & M & $\begin{array}{l}\text { Unilocular radiolucent } \\
\text { area }\end{array}$ & $\begin{array}{l}\text { spindle-shaped cells intermingled with a } \\
\text { delicate fibrillar stroma along with mast } \\
\text { cells }\end{array}$ & $\begin{array}{l}\text { S-100 and anti-Leu } \\
\text { positive }\end{array}$ \\
\hline $\begin{array}{l}\text { Papadopou- } \\
\text { los 1981[16] }\end{array}$ & 15 & M & Radiolucency & $\begin{array}{l}\text { Neoplastic cells with ovoidal, elongated } \\
\text { nucleus; No pleomorphism; No encap- } \\
\text { sulation }\end{array}$ & Not reported \\
\hline
\end{tabular}




\begin{tabular}{|c|c|c|c|c|c|}
\hline $\begin{array}{l}\text { Gnepp } \\
1981[17]\end{array}$ & 24 & $\mathrm{~F}$ & $\begin{array}{l}\text { Non expansile, moder- } \\
\text { ately well-defined uni- } \\
\text { locular radiolucent }\end{array}$ & $\begin{array}{l}\text { Bundles of mildly pleomorphic spindle } \\
\text { shaped cells in fibrous stroma }\end{array}$ & Not reported \\
\hline $\begin{array}{l}\text { Gnepp } \\
\text { 1981[17] }\end{array}$ & 39 & $\mathrm{~F}$ & $\begin{array}{l}\text { Well demarcated, slightly } \\
\text { expansile, unilocular ra- } \\
\text { diolucent }\end{array}$ & $\begin{array}{l}\text { Interlacing bundles of elongated spindle } \\
\text { shaped cells in fibrous stroma }\end{array}$ & Not reported \\
\hline $\begin{array}{l}\text { Larsson } \\
1978[18]\end{array}$ & 25 & $\mathrm{~F}$ & Extense bone resorption & $\begin{array}{l}\text { Irregular nerve fiber strands intermin- } \\
\text { gled with collagen fibers and abundant } \\
\text { cells }\end{array}$ & Not reported \\
\hline $\begin{array}{l}\text { Larsson } \\
1978[18]\end{array}$ & 46 & M & $\begin{array}{l}\text { Bone destruction with } \\
\text { slightly radiopaque areas }\end{array}$ & $\begin{array}{l}\text { Spindle cell with elongated or oval nu- } \\
\text { clei forming cords }\end{array}$ & Not reported \\
\hline Ellis 1977[19] & 41 & $\mathrm{~F}$ & $\begin{array}{l}\text { Poorly defined multiloc- } \\
\text { ulated radiolucency }\end{array}$ & $\begin{array}{l}\text { Slight morphologic variability in cells } \\
\text { with no mitotic activity }\end{array}$ & Not reported \\
\hline Ellis 1977[19] & 4 & $\mathrm{~F}$ & $\begin{array}{l}\text { Well demarcated radio- } \\
\text { lucency }\end{array}$ & $\begin{array}{l}\text { Abundance of small nerves with several } \\
\text { enlarged nerve fascicles }\end{array}$ & Not reported \\
\hline Ellis 1977[19] & 8 & M & $\begin{array}{l}\text { Well demarcated radio- } \\
\text { lucency with sclerotic } \\
\text { borders }\end{array}$ & $\begin{array}{l}\text { Dense, wavy tissue of collagenous type } \\
\text { with fibers in random orientation and } \\
\text { cells with spindle shaped nuclei with no } \\
\text { mitotic figure }\end{array}$ & Not reported \\
\hline Ellis 1977[19] & 23 & $\mathrm{~F}$ & $\begin{array}{l}\text { Indistinct radiolucent- } \\
\text { radioopaque lesion }\end{array}$ & $\begin{array}{l}\text { Loose, myxomatous and fibrillary na- } \\
\text { ture with more abundant mucoid matrix }\end{array}$ & Not reported \\
\hline Ellis 1977[19] & 4 & $\mathrm{M}$ & $\begin{array}{l}\text { Multilocular radiolu- } \\
\text { cency }\end{array}$ & $\begin{array}{l}\text { Dense, wavy tissue of collagenous type } \\
\text { with fibers in random orientation and } \\
\text { cells with spindle shaped nuclei with no } \\
\text { mitotic figure }\end{array}$ & Not reported \\
\hline $\begin{array}{l}\text { Singer } \\
1973[20]\end{array}$ & 30 & $\mathrm{~F}$ & $\begin{array}{l}\text { Radiolucent fusiform en- } \\
\text { largement }\end{array}$ & $\begin{array}{l}\text { Interlacing cords of fusiform cells with } \\
\text { thin tapering nuclei associated with fi- } \\
\text { brillar stroma }\end{array}$ & Not reported \\
\hline $\begin{array}{l}\text { Cundy } \\
1972[21]\end{array}$ & 55 & $\mathrm{~F}$ & Large radiolucency & $\begin{array}{l}\text { spindle cells with ovoid nuclei arranged } \\
\text { in parallel rows with intertwining fasci- } \\
\text { cles }\end{array}$ & Not reported \\
\hline $\begin{array}{l}\text { Prescott } \\
1970[22]\end{array}$ & 5 & M & $\begin{array}{l}\text { Circumscribed radiolu- } \\
\text { cent }\end{array}$ & $\begin{array}{l}\text { Irregular bundles of nerve tissue and } \\
\text { whorls with ovoid elongated and com- } \\
\text { ma shaped basophilic nuclei and pale } \\
\text { acidophilic cytoplasm }\end{array}$ & Not reported \\
\hline $\begin{array}{l}\text { Cassalia } \\
1971[2]\end{array}$ & 16 & $\mathrm{~F}$ & $\begin{array}{l}\text { Multilocular radiolu- } \\
\text { cency }\end{array}$ & $\begin{array}{l}\text { delicate intertwining network of colla- } \\
\text { gen fibres together with numerous small } \\
\text { nerve fibrils }\end{array}$ & Not reported \\
\hline $\begin{array}{l}\text { Sharawy } \\
1968[23]\end{array}$ & 22 & $\mathrm{~F}$ & Multilocular radiolucent & $\begin{array}{l}\text { Delicate connective tissue fibrils, fibro- } \\
\text { blasts and nerve tissue with few woven } \\
\text { bone trabeculae }\end{array}$ & Not reported \\
\hline $\begin{array}{l}\text { Gutman } \\
1964[24]\end{array}$ & 5 & $\mathrm{~F}$ & $\begin{array}{l}\text { Unilocular, translucent } \\
\text { area }\end{array}$ & $\begin{array}{l}\text { Spindle cells arranged in ranks or small } \\
\text { whorls embedded in a non-cellular, col- } \\
\text { lagenous, connective tissue; No signs of } \\
\text { malignancy }\end{array}$ & Not reported \\
\hline $\begin{array}{l}\text { Villa } \\
1962[25]\end{array}$ & 2.5 & $\mathrm{M}$ & Radiolucent lesion & $\begin{array}{l}\text { Infiltrating small bands of skeletal mus- } \\
\text { cle; Inferior alveolar nerve showed in- } \\
\text { crease in fibrous tissue }\end{array}$ & Not reported \\
\hline
\end{tabular}




\begin{tabular}{|c|c|c|c|c|c|}
\hline $\begin{array}{l}\text { Caldwell } \\
1961[1]\end{array}$ & 2.5 & $\mathrm{M}$ & Radiolucent lesion & $\begin{array}{l}\text { Infiltrating small bands of skeletal mus- } \\
\text { cle; Inferior alveolar nerve showed in- } \\
\text { crease in fibrous tissue }\end{array}$ & Not reported \\
\hline $\begin{array}{l}\text { Johnson } \\
1959[26]\end{array}$ & 34 & $\mathrm{~F}$ & Radiolucent & $\begin{array}{l}\text { Interlacing bundles of elongated spindle } \\
\text { shaped cells with wavy nuclei }\end{array}$ & Not reported \\
\hline $\begin{array}{l}\text { Cornell } \\
1955[27]\end{array}$ & 65 & $\mathrm{~F}$ & $\begin{array}{l}\text { Cystic character with not } \\
\text { well defined borders }\end{array}$ & $\begin{array}{l}\text { Encapsulated tumor with thick myelinic } \\
\text { nerve filaments towards the centre }\end{array}$ & Not reported \\
\hline $\begin{array}{l}\text { Bruce } \\
1954[28]\end{array}$ & 36 & $\mathrm{M}$ & $\begin{array}{l}\text { Osteolysis in mandibular } \\
\text { alveolus }\end{array}$ & $\begin{array}{l}\text { Rows of palisaded nuclei separated by a } \\
\text { band of fibers without nuclei }\end{array}$ & Not reported \\
\hline $\begin{array}{l}\text { Blackwood } \\
1951[29]\end{array}$ & 41 & M & Large radiolucent area & $\begin{array}{l}\text { Type A: parallel arrangement of cells and } \\
\text { intercellular fibres giving a regimented } \\
\text { appearance; Type B: loose meshwork of } \\
\text { cells and shows the presence of numer- } \\
\text { ous intercellular vacuoles or microcysts }\end{array}$ & Not reported \\
\hline $\begin{array}{l}\text { Goldman } \\
1944[30]\end{array}$ & 33 & $\mathrm{M}$ & Large cystic lesion & $\begin{array}{l}\text { Reticulated mesenchymal tissue with } \\
\text { occasional nerve filaments. Spindle } \\
\text { shaped cells with small nuclei arranged } \\
\text { in bundles }\end{array}$ & Not reported \\
\hline
\end{tabular}

Lastly, the choice of treatment for this clinical case should be discussed. Marx states in Oral and Maxillofacial Pathology - 2nd Ed: "In contrast to the schwannoma, a neurofibroma arises from the internal portion of a nerve clinically. In most cases the parent nerve is not identifiable. In some cases the nerve can be seen to enter the proximal end of the tumor (Figures 10-32a and 10-32b). Because the nerve is incorporated into and is actually part of the neurofibroma, it cannot be preserved (Figure 10-33)." p.421 (Oral and Maxillofacial Pathology, 2nd Edition) [36]."

Although the surgical treatment of a neurofibroma as outlined by Marx may not involve the preservation of the incorporated nerve, we believe our choice of treatment was appropriate in this particular case. Several factors were taken into consideration when determining the appropriate course of treatment with this particular patient; such factors include occurrence and recurrence rates of neurofibromas in the oral cavity, absence of Von Recklinghausen's Disease (VRD), likelihood of malignant transformation, patient age, patient informed consent, and size/localization of the lesion. Due to the fact that this patient did not present with VRD, it was extremely rare that this individual would develop a neurofibroma in her lifetime, especially in the head and neck region. As previously stated, it is believed that approximately $5 \%$ of neurofibromas arise in the oral cavity [33]. Furthermore, at 70 years of age it was deemed highly unlikely for this individual to experience recurrence of the neurofibroma once excised. There is a significant lack of literature surrounding neurofibroma recurrence rates in the oral cavity due to their rarity. Some sources simply state the likelihood of recurrence as "rare" in the case of Alatli et al [11] while other sources attempt to quantitatively measure the rate of recurrence as less than $20 \%$ [37].
Additionally, the possibility of malignant transformation of the tumor was discussed. It is estimated that the risk of developing a malignant transformation in neurofibromas is approximately $2-5 \%$ [38]. With that being said, the prospect of this patient presenting with recurring neurofibroma of the oral cavity with a malignant transformation at $70+$ years of age is highly unlikely.

Moreover, the patient's intentions were taken into account. The risks outlined above were discussed with the patient in detail providing full informed consent. With these risks in mind, the patient elected a surgical approach that would attempt to fully excise the lesion while preserving the inferior alveolar nerve and therefore preserve sensory perception in the regions innervated by this nerve. Lastly, due to the relatively small size of the lesion in question, as well as the apparent localization, the surgical decision to perform blunt and sharp dissections of the lesion was carried out.

We believe that the treatment decision should involve a multi-factorial approach. Although this approach may not coincide with that of Marx, we were able to achieve success with exemplary results.

\section{Conclusion}

It is important for dental practitioners to be aware of the radiographic and clinical presentation of neurofibromas and their manifestation in the oral cavity. The recognition of neurofibromas is critical as they could be the initial manifestation of neurofibromatosis. Although neurofibromas are benign, there have been reports of neurofibroma recurrence and transformation into malignant tumors. As such, it is essential to conduct clinical and radiographical examination, as well as long term follow up to ensure there is no recurrence. 


\section{References}

1) Caldwell JB, Hughes KW, Cox RS (1961) Neurofibroma of the mandible: Report of case. J Oral Surg.19:166.

2) Cassalia PT, Miller AS (1971) Solitary central neurofibroma of the mandible. Br J Oral Surg. Mar 8: 270-272.

3) Cheng SF, Chen YI, Chang CY, Peng Y, Liao SL (2008) Malignant peripheral nerve sheath tumor of the orbit: Malignant transformation from neurofibroma without neurofibromatosis. Ophthal Plast Reconstr Surg. 24: 413-415.

4) Vivek N, Manikandhan R, James PC, Rajeev R (2006) Solitary intraosseous neurofibroma of mandible. Indian J Dent Res.17:135-138.

5) Gujjar PK, Hallur JM, Patil ST, et al. (2015) The Solitary Variant of Mandibular Intraosseous Neurofibroma: Report of a Rare Entity. Case Reports in Dentistry 2015:520261.

6) Jangam SS , Ingole SN , Deshpande MD , Ranadive PA (2014) Solitary intraosseous neurofibroma: Report of a unique case. Contemp Clin Dent. 5: 561-563.

7) Deichler J, Martínez R, Niklander S, Seguel H, Marshall M, Esguep A (2011) Solitary intraosseous neurofibroma of the mandible. Apropos of a case. Med Oral Patol Oral Cir Bucal.16:e704-e707.

8) Tao Q, Wang Y, Zheng C (2010) Neurofibroma in the left mandible: a case report. Kaohsiung J Med Sci. 26: 217-221.

9) Depprich R, Singh DD, Reinecke P, Kübler NR, Handschel J (2009) Solitary submucous neurofibroma of the mandible: review of the literature and report of a rare case. Head \& Face Medicine 5:24.

10) Apostolidis C, Anterriotis D, Rapidis AD, Angelopoulos AP (2001) Solitary intraosseous neurofibroma of the inferior alveolar nerve: report of a case. J Oral Maxillofac Surg 59:232-235.

11) Alatli C, Oner B, Unür M, Erseven G (1996) Solitary plexiform neurofibroma of the oral cavity A case report. Int J Oral Maxillofac Surg 25:379-380.

12) Ueda M , Suzuki H, Kaneda $T$ (1993) Solitary intraosseous neurofibroma of the mandible: report of a case. Nagoya J Med Sci 55:97101.

13) Papageorge MB, Doku HC, Lis R (1992) Solitary neurofibroma of the mandible and infratemporal fossa in a young child. Report of a case. Oral Surg Oral Med Oral Pathol. 73:407-411.

14) Weaver BD, Graves RW, Keyes GG, Lattanzi DA (1991) Central neurofibroma of the mandible: report of a case. J Oral Maxillofac Surg 49:1243-1246.

15) Polak M, Polak G, Brocheriou C, Vigneul J (1989) Solitary neurofibroma of the mandible: Case report and review of the literature. J Oral Maxillofac Surg 47:65-68.

16) Papadopoulos H, Zachariades N, Angelopoulos AP (1981) Neurofibroma of the mandible. Review of the literature and report of a case. Int J Oral Surg 10: 293-297.

17) Gnepp DR. Keyes GG (1981) Central neurofibromas of the mandible: report of two cases. J Oral Surg 39:125.

18) Larsson A, Praetorius F, Hjörting-Hansen E (1978) Intraosseous neurofibroma of the jaws. Int J Oral Surg 7:494-499.

19) Ellis GL. Abrams AM, Melrose RJ (1977) Intraosseous benign neural sheath neoplasms of the jaws: Report of seven new cases and review of the literature. Oral Surg 44:731.

20) Singer CF. Gienger GL, Kullbom TL (1973) Solitary intraosseous neurofibroma involving the mandibular canal: Report of case. J Oral Surg 31:127.

21) Cundy RL, Matukas VJ (1972) Solitary intraosseous neurofibroma of the mandible. Arch Otolaryngol $96: 81-83$.
22) Prescott GH, White RE. Solitary (1970) central neurofibroma of the mandible: report of case and review of the literature. J Oral Surg 28:305-309.

23) Sharawy A. Springer J (1968) Central neurofibroma occurring in the mandible. Oral Surg 25:817.

24) Gutman D, Griffel B, Munk J, Shohat S (1964) Solitary neurofibroma of the Mandible. Oral Surg Oral Med Oral Pathol 17:1-9.

25) Villa VG, Laico JE, Banez LO (1962) Central neurofibroma in the mandible associated with occasional spontaneous hemorrhage. Report of a case. Oral Surg Oral Med Oral Pathol 15:836-842.

26) Johnson HS, Wannamaker GT, Humes JJ, et al. (1959) Central neurofibroma: Report of a case. Oral Surg 12:379.

27) Cornell CF. Vargas HA (1955) Intraosseous neurofibroma of the mandible. Oral Surg. 8:34.

28) Bruce KW (1954) Solitary neurofibroma (neurilemmoma, schwannoma) of the oral cavity. Oral Surg Oral Med Oral Pathol 7: 150-159.

29) Blackwood HJ, Lucas RB (1951) Neurofibroma of the mandible. Proc R Soc Med. 44:864-865.

30) Goldman HM (1944) Case reports from the army medical museum. Am J Orthod 30:289.

31) Misra S, Gogri P, Misra N, Bhandari A (2013) Recurrent neurofibroma of the orbit. The Australasian Medical Journal 6:189-191.

32) Krol E, El-Fanek H, Borruso J (2015) Solitary Neurofibroma with Malignant Transformation: Case Report and Review Of Literature 79:217-219.

33) Borges AH, Correia RDM, Borba AM, Guedes OA, Estrela CRDA, Bandeca MC (2013) Unusual solitary neurofibroma on the lower lip of a child. Contemporary Clinical Dentistry. 4: 512-514.

34) Jenne, DE, Tinschert $S$, Reimann $H$, Lasinger $W$, Thiel G, et al. (2001) Molecular characterization and gene content of breakpoint boundaries in patients with neurofibromatosis type 1 with $17 \mathrm{q} 11.2$ microdeletions. Am. J. Hum. Genet. 69: 516-527.

35) Roy P, Chakraborty S, Das S, Roy A (2015) Solitary neurofibroma at the base of the tongue: A rare presentation. Indian J Dermatol 60:497-499.

36) Diane Stern DDS, MS, Robert E. Marx, DDS (2012) Oral and Maxillofacial Pathology - (2nd Edn) Hanover Park, Illinois. Quintessence Publishing Co, Inc.

37) Asha'ari ZA, Kahairi A, Shahid H (2012) Surgery for massive paediatric head and neck neurofibroma: two case reports. The International Medical Journal Malaysia 11: 54-57.

38) Bader JL (1986) Neurofibromatosis and Cancer. Annals of the New York Academy of Sciences, 486: 57-65.

Submit your manuscript to a JScholar journal and benefit from:

๑ Convenient online submission

I Rigorous peer review

- Immediate publication on acceptance

बा Open access: articles freely available online

ब High visibility within the field

ब Better discount for your subsequent articles Submit your manuscript at http://www.jscholaronline.org/submit-manuscript.php 